\title{
Retraction Note: \\ PEDF inhibits VEGF- and EPO- induced angiogenesis in retinal endothelial cells through interruption of PI3K/Akt phosphorylation
}

\author{
Banumathi Elayappan - Haribalaganesh Ravinarayannan • \\ Sheik Pran Babu Sardar Pasha · Kyung-jin Lee • \\ Sangiliyandi Gurunathan
}

Published online: 17 July 2011

(C) Springer Science+Business Media B.V. 2011

\section{Retraction to: Angiogenesis}

DOI 10.1007/s10456-009-9153-5

This article has been retracted at the request of the Editors as it contains manipulated figures.

In Fig. 4, paper photomicrographs are supposed to represent images of endothelial cell cultures after scratching the monolayer in order to assess migration of the cells. However, the panels do not represent independent data, but instead contain repetitive cell patterns suggestive of digital manipulation of these figures.

As such, this article represents a severe abuse of the scientific publishing system. The scientific community and the Editors take a very strong view on this matter, and apologies are offered to readers of the journal that this problem was not detected during the submission and review process.

It has been found that other articles from the same laboratory also contain manipulated figures. We have listed those articles below.

The online version of the original article can be found under doi:10.1007/s10456-009-9153-5.

B. Elayappan - H. Ravinarayannan - S. P. B. Sardar Pasha ·

S. Gurunathan $(\square)$

Department of Biotechnology, Division of Molecular and Cellular Biology, Kalasalingam University (Kalasalingam Academy of Research and Education), Anand Nagar, Krishnankoil, Madurai, Tamil Nadu 626190, India

e-mail: lvsangs@yahoo.com

K. Lee

Department of Life Science, Cell Dynamics Research Centre, Gwangju Institute of Science and Technology,

Gwangju 500 712, Korea
Pigment epithelium-derived factor inhibits vascular endothelial growth factor-and interleukin-1beta-induced vascular permeability and angiogenesis in retinal endothelial cells. Sheikpranbabu S, Ravinarayanan H, Elayappan B, Jongsun P, Gurunathan S. Vascul Pharmacol. 2010 Jan-Feb;52(1-2):84-94. Epub 2009 Dec 16.

Pigment epithelium-derived factor inhibits erythropoietin-induced retinal endothelial cell angiogenesis by suppression of PI3K/Akt pathway. Haribalaganesh R, Sheikpranbabu S, Banumathi E, Gurunathan S. Exp Eye Res. 2010 Jun;90(6):726-33. Epub 2010 Mar 16.

Isolation and characterization of goat retinal microvascular endothelial cells. Haribalaganesh R, Banumathi E, Sheikpranbabu S, Deepak V, Sirishkumar N, Gurunathan S. In Vitro Cell Dev Biol Anim. 2010 Jun;46(6):529-37. Epub 2010 Mar 7.

High-yielding enzymatic method for isolation and culture of microvascular endothelial cells from bovine retinal blood vessels. Banumathi E, Haribalaganesh R, Babu SS, Kumar NS, Sangiliyandi G. Microvasc Res. 2009 May;77(3):377-81. Epub 2009 Feb 21.

Pigment epithelium-derived factor inhibits advanced glycation end-product-induced angiogenesis and stimulates apoptosis in retinal endothelial cells. Sardarpasha Sheikpranbabu, Ravinarayanan Haribalaganesh, Elayappan Banumathi, Namagiri Sirishkumar, Kyung-Jin Lee, Sangiliyandi Gurunathan Life Sciences. 2009 November; 85(21-22):719-31. Epub 2009 October 8.

Gold nanoparticles inhibit vascular endothelial growth factor-induced angiogenesis and vascular permeability via Src-dependent pathway in retinal endothelial cells. Kalishwaralal K, Sheikpranbabu S, BarathManiKanth S, 
Haribalaganesh R, Ramkumarpandian S, Gurunathan S. Angiogenesis 2011 Mar;14(1):29-45. Epub 2010 November 9 .

"PEDF inhibits VEGF- and EPO-induced angiogenesis in retinal endothelial cells through interruption of PI3K/Akt phosphorylation". Banumathi Elayappan, Haribalaganesh Ravinarayannan, Sheik Pran Babu Sardar Pasha, Kyung-jin Lee and Sangiliyandi Gurunathan. Angiogenesis 2009, Dec 12(4):313-324. Epub 2009 August 6.
"PEDF prevents reactive oxygen species generation and retinal endothelial cell damage at high glucose levels". Elayappan Banumathi, Sardarpasha Sheikpranbabu, Ravinarayanan Haribalaganesh, Sangiliyandi Gurunathan. Exp Eye Res. 2010 90(1):89-96. Epub 2009 October 16.

The Editors 